\title{
Influence of biopreparations on the content of proline and chlorophyll Sorghum bicolor L. in Steppe conditions
}

Abdurashytova E.R., Abdurashytov S.F., Turin E.E.

Research Institute of agriculture of Crimea, Simferopol, Crimea

E-mail: elvi-jadore@mail.ru

Key message. The use of biopreparations on sorghum contributed to a $38.2 \%$ increase in proline and 1.4 times more yields in a dry year, and in a favorable year, seed pre-sowing inoculation reduced the concentration of proline (by 49.8\%) and chlorophyll (by $6.5 \%)$.

Keywords: drought, proline, chlorophylls, complex of microbial preparations, sorghum

Plant drought stress is associated with the accumulation of low-molecular weight substances such as proline. Proline, which can perform an antioxidant and membrane-stabilizing function and may affect on the photosynthetic apparatus indirectly through an osmotic effect [1].

The aim of the work was to study the effect of the complex of microbial preparations (CMP) on the content of proline and chlorophylls in Sorghum bicolor L. grown by no-till technology in the Crimean Steppe.

Sorghum (Krymbel variety) was grown in 2018-2019 in a stationary field experiment with five-field crop rotation on southern chernozem. CMP based on strains of associative bacteria and arbuscular mycorrhizal fungi (AMF) were used for presowing treatment of seeds. In the control version, biological treatment was not performed. To assess the changes in physiological and biochemical processes in plants during the sweeping phase, the content of proline [2] and chlorophyll [3] was determined, and sorghum grain productivity was also taken into account.

The initial period of vegetation of sorghum in 2018 was characterized by atmospheric drought and less rainfall compared to the long-term average. According to the data obtained, the use of biological products contributed to increasing the resistance of plants to drought by increasing the proline content in the leaves by $38.2 \%$ compared with the control ( $38.3 \mu \mathrm{g} / \mathrm{g}$ of plant). The chlorophylls content in the studied variants remained unchanged at $14.8 \mathrm{mg} / \mathrm{g}$ of the plant. The productivity in the control was $1.52 \mathrm{t} / \mathrm{ha}$, the use of CMP with AMF increased it by 1.4 times.

Against the backdrop of favorable weather conditions in 2019, the proline content in the control was lower than 42.5\%, and chlorophylls were higher by $14.7 \%$ than in 2018 . When using the ILC, the concentration of proline and chlorophylls decreased by $49.8 \%$ and $6.5 \%$, respectively, compared with the control without treatment. These data testified to insignificance of stresses when using biological products in 2019. There are no changes in yield in the conditions of this year were observed.

Thus, it was noted that the use of biopreparation with S. bicolor contributed to an increase the proline content by $38.2 \%$ and a 1.4 -fold increase in sorghum yield in a dry year relative to the untreated control. And in a favorable year, pre-sowing inoculation of sorghum seeds reduced the concentration of proline (by $49.8 \%$ ) and chlorophylls (by $6.5 \%$ ).

\section{Влияние биопрепаратов на содержание пролина и хлорофилла в Sorghum bicolor L., выращенного по технологии прямого посева \\ Абдурашитова Э.Р., Абдурашитов С.Ф., Турин Е.Е.}

ФГБУН «Научно-исследовательский институт сельского хозяйства Крыма», Симферополь, Республика Крым

Аннотация. Применение биопрепаратов на сорго способствовало повышению содержания пролина на $38,2 \%$ и урожсайности в
1,4 раза в засушливый год, а в благоприятный год предпосевная инокуляция семян снижала концентрацию пролина (на 49,8 \%) и хлорофиллов (на 6,5\%).

Ключевые слова: засуха, пролин, хлорофилль, комплекс микробных препаратов, сорго зерновое

Вызываемый засухой стресс растений связан с накоплением низкомолекулярных веществ, таких как пролин, который может выполнять антиоксидантную и мембраностабилизирующую функцию и воздействовать на фотосинтетический аппарат опосредованно, через осмотическое действие [1].

Целью работы являлось изучение влияния комплекса микробных препаратов (КМП) на содержание пролина и хлорофилла в растениях Sorghum bicolor L., выращенного по технологии прямого посева (ПП) в Степи Крыма.

Сорго зерновое сорта Крымбел выращивали в 2018-2019 гг. в пятипольном севообороте в условиях стационарного полевого опыта по изучению ПП на черноземе южном. КМП на основе штаммов ассоциативных бактерий и арбускулярно-микоризных грибов (АМГ) применяли для предпосевной обработки семян. В контрольном варианте обработку биопрепаратами не проводили. Для оценки изменения физиолого-биохимических процессов в растениях в фазу выметывания определяли содержание пролина [2] и хлорофиллов [3], а также проводили учет зерновой продуктивности сорго.

Начальный период вегетации сорго в 2018 г. характеризовался атмосферной засухой и меньшим количеством осадков по сравнению со средней многолетней. Согласно полученных данных применение биопрепаратов способствовало увеличению устойчивости растений к засухе повышением содержания пролина в листьях на 38,2 \% по сравнению с контролем (38,3 мкг/г растения). Содержание хлорофиллов в исследуемых вариантах осталось неизменным 14,8 мг/г растения. Урожайность в контроле составила 1,52 т / га, применение КМП с АМГ повысило ее в 1,4 раза.

На фоне благоприятных погодных условий 2019 г. содержание пролина в контроле было меньшим 42,5 \%, а хлорофиллов - выше на $14,7 \%$, чем в 2018 г. При использовании КМП концентрация пролина и хлорофиллов уменьшилась на 49,8 \% и 6,5 \% соответственно по сравнению с контролем без обработки. Эти данные свидетельствовали об незначительности стрессов при использовании биопрепаратов в 2019 г. Изменения урожайности в условиях этого года не наблюдали.

Таким образом, отмечено, что применение биопрепаратов с S. bicolor способствовало повышению содержания пролина на $38,2 \%$ и урожайности сорго в 1,4 раза в засушливый год по отношению необработанному контролю. А в благоприятный год предпосевная инокуляция семян сорго снижала концентрацию пролина (на 49,8 \%) и хлорофиллов (на 6,5 \%).

1. Rapacz M., Wójcik-Jagła M., Fiust A., Kalaji H. M., Kościelniak J. Genome-wide associations of chlorophyll fluorescence OJIP transient parameters connected with soil drought response in barley / Plant Sci., 2019.

2. Шихалеева, Г. Н. Модифікована методика визначення проліну в рослинних об'єктах / Г.Н. Шихалеева, А.К. Будняк, И.И. Шихалеев, О.Л. Иващенко // Вісник Харківського національного університету імені В.Н. Каразіна. Серія: Біологія. 2014. - Вип. 21. №1112. - С. 168-172.

3. Специальный практикум по биохимии и физиологии растений / М.М. Окунцов, К.Г. Врублевская, В.М. Гольд [и др.]. - Томск: Изд-во Томского университета, 1966 г. - 103 с. 